
ОБСТРУКТИВНЕ ЗАХВОРЮВАННЯ ЛЕГЕНЬ ІЗ СУПУТНІМ ЦУКРОВИМ ДІАБЕТОМ ТИПУ 2

\title{
Н.В. Чернецька
}

Вищий державний навчальний заклад України «Буковинський державний медичний університет», м. Чернівці, Україна

Ключові слова: хронічне обструктивне захворювання легень, иукровий діабет типу 2, аторвастатин, лікування.

Буковинський медичний вісник. T.24, № 1 (93). C. 188-194.

\section{DOI:}

10.24061/2413-0737.

XXIV.1.93.2020.25

\section{E-mail:}

chernetskanataliia @ukr.net
Мета роботи - вивчити ефективність застосування аторвастатину у хворих на хронічне обструктивне захворювання легень (ХОЗЛ) із супутнім иукровим діабетом (ЦД) типу 2.

Матеріал і методи. Обстежено 49 хворих на ХОЗЛ із супутнім ЦД типу 2. Пачіснтам, окрім стандартної терапії, призначали аторвастатин 20-40 мг 1 раз на добу впродовж шести місяців.

При обстеженні паиієнтів використовували САТ-тест, тест із 6-хвилинною ходьбою, інтегральний індекс BODE, спірометрію, біоімпедансний аналіз. У динамічі лікування оиінювали також ліпідний спектр крові, вуглеводний обмін, функиіональний стан ендотелію, рівень лептину, адипонектину, резистину, фактора некрозу пухлин- $\alpha$ (ФНПа), трансформуючого фактора росту- $\beta 1$ (ТФР $\beta 1)$ та С-реактивного білка (СРБ) у сироватиі крові. Результати. При аналізі показників біоімпедансометрії в динаміиі лікування аторвастатином у хворих на ХОЗЛ із супутнім ЦД типу 2 встановлено достовірне зниження відсотка жирової маси, вісиерального жиру та IMT. При очіниі спірометрії, відзначалась тенденція до зростання ОФВ1, проте достовірності не було ( $p>0,05)$.

Через шість місяиів лікування аторвастатином у хворих на ХОЗЛ із супутнім ЦД типу 2 спостерігалось достовірне зниження задишки на 61,8\% ( $p>0,05)$, зменшення кількості балів за САТ-тестом на 40,7\% ( $p<0,001)$ ma зростання відстані пройденої за 6 хв на 14,9\% (p<0,001). Інтегральний індекс BODE наприкіниі лікування зменшувався на 49,9\% (p<0,001).

Аналіз показників ліпідного спектра крові показав достовірне зниження загального ХС, ХС ЛПНЩ, ХС ЛПДНЩ, ТГ (p<0,001), проте ХС ЛПВЩ достовірних змін не зазнавав ( $p>0,05)$.

Рівні адипоцитокінів (лептину та резистину), ФНПа, ТФРß1 та СРБ у сироватиі крові при використанні аторвастатину у хворих на ХОЗЛ із супутнім ЦД типу 2 достовірно знижувалися за відсутності достовірних змін адипонектину ( $>>0,05)$.

Аналіз показників функиіонального стану ендотелію наприкінці лікування показав вірогідне зростання рівня нітратів/нітритів на 35,3\% $(p<0,001)$, зниження КЦЗЕ у 2 рази $(p<0,001)$ та ЕT-1 у 2,3 раза $(p<0,001)$.

За результатами дослідження, аторвастатин достовірно не впливав на вуглеводний обмін, але покращував ліпідний спектр крові. Отже, у паиієнтів на ХОЗЛ із супутнім ЦД типу 2 використання аторвастатину не погіршує перебіг ЦД, проте, можливо, призводить до зменшення кардіоваскулярного ризику, покращуючи показники вуглеводного обміну.

Враховуючи, щз статини покращують функиіональний стан ендотелію, вивчався вплив аторвастатину на ендотеліальну дисфункиію у хворих на ХОЗЛ із супутнім ЦД типу 2. Встановлено зростання рівня нітратів/нітритів та зниження КЦЗЕ, рівня ЕT-1 у сироватщі крові.

Висновки. Отже, шестимісячне застосування аторвастатину в комплексному лікуванні хворих на хронічне обструктивне захворювання легень 
Original research

із супутнім иукровим діабетом типу 2 покращує склад тіла, толерантність хворих до фізичного навантаження, якість життя, прогноз та зменшує тяжкість перебігу коморбідної патологї̈ на тлі зниження проявів системного запалення, ендотеліальної дисфункиї із покращенням ліпідного спектра крові.

\section{Ключевые слова: хронические обструктивные заболевания легких, сахарный диабет типа 2, аторвастатин, лечение.}

Буковинский медицинский вестник. T.24, № 1 (93). C. 188-194.

\section{ЭФФЕКТИВНОСТЬ ПРИМЕНЕНИЯ АТОРВАСТАТИНА У БОЛЬНЫХ ХРОНИЧЕСКИМ ОБСТРУКТИВНЫМ ЗАБОЛЕВАНИЕМ ЛЕГКИХ С СОПУТСТВУЮЩИМ САХАРНЫМ ДИАБЕТОМ 2-ГО ТИПА}

Н.В. Чернецкая

Цель работы - изучить эффективность применения аторвастатина у больных хроническим обструктивным заболеванием легких (ХОБЛ) с сопутствуюшим сахарным диабетом (СД) 2-го типа.

Материал и методы. Обследовано 49 пациентов ХОБЛ с сопутствующим СД типа 2. Пачиентам, кроме стандартной терапии, назначали аторвастатин 20-40 мг 1 раз в сутки в течение шести месяиев.

При обследовании пациентов использовали САТ-тест, тест с 6-минутной ходьбой, интегральный индекс BODE, спирометрию, биоимпедансный анализ. В динамике лечения оиенивали также липидный спектр крови, углеводный обмен, функииональное состояние эндотелия, уровень лептина, адипонектина, резистина, фактора некроза опухолей- $\alpha$ (ФНП $)$, трансформирующего фактора роста- $\beta 1$ (ТФР $\beta 1)$ и С-реактивного белка (СРБ) в сыворотке крови.

Результаты. При анализе показателей биоимпедансометрии в динамике лечения аторвастатином у больных ХОБЛ с сопутствующим СД 2-го типа установлено достоверное снижение проиента жировой массы, висиерального жира и ИМТ. При оченке спирометрии, отмечалась тенденция $\kappa$ росту ОФВ1, однако достоверности не было ( $p>0,05)$.

Через шесть месяиев лечения аторвастатином у больных ХОБЛ с сопутствуюшим СД 2-го типа наблюдалось достоверное снижение одышки на 61,8\% (p <0,05), уменьшение количества баллов по САТ-тестом на 40,7\% ( $p<0,001)$ и роста расстояния пройденной за шесть минут на $14,9 \%$ ( $p$ $<0,001)$. Интегральный индекс BODE в конще лечения уменьшался на 49,9\% $(p<0,001)$.

Анализ показателей липидного спектра крови показал достоверное снижение общего ХС, ХС ЛПНП, ХС ЛПОНП, ТГ ( $<<0,001)$, однако ХС ЛПВП достоверных изменений не испытывал $(p>0,05)$.

Уровни адипоцитокинов (лептина и резистина), ФНП , ТФР 1 и СРБ в сыворотке крови при использовании аторвастатина у больных ХОБЛ с сопутствующим СД 2-го типа достоверно снижались при отсутствии достоверных изменений адипонектина $(p>0,05)$.

Анализ показателей функиионального состояния эндотелия в коние лечения показал вероятен рост уровня нитратов/нитритов на 35,3\% ( $<<0,001)$, снижение КЦЗЕ в 2 раза ( $<<0,001)$ и ET-1 в 2,3 раза $(p<0,001)$.

По результатам исследования, аторвастатин достоверно не влиял на углеводный обмен, но улучшал липидный спектр крови. Так, у пачиентов ХОБЛ с сопутствующим СД 2-го типа использование аторвастатина не ухудшает течение СД, однако, возможно, приводит к уменьшению кардиоваскулярного риска, улучшая показатели углеводного обмена.

Учитывая, что статины улучшают функциональное состояние эндотелия, изучалось влияние аторвастатина на эндотелиальную дисфункиию 
у больных ХОБЛ с сопутствующим СД типа 2. Установлено рост уровня нитратов/нитритов и снижение КЦЗЕ и уровня ЭТ-1 в сыворотке крови. Выводы. Итак, шестимесячное применение аторвастатина в комплексном лечении больных ХОБЛ с сопутствующим СД 2-го типа улучшает состав тела, толерантность больных к физической нагрузке, качество жизни, прогноз и уменьшает тяжесть течения коморбидной патологии на фоне снижения проявлений системного воспаления, эндотелиальной дисфункиии с улучшением липидного спектра крови.

Keywords: chronic obstructive pulmonary disease, type 2 diabetes, atorvastatin, treatment.

Bukovinian Medical Herald. V.24, № 1 (93). P. 188-194.

\section{EFFECTIVENESS OF ATORVASTATIN APPLICATION IN PATIENTS WITH CHRONIC OBSTRUCTIVE LUNG DISEASE WITH CONCOMITANT DIABETES TYPE 2}

N.V. Chernetska

The aim of the study was to study the efficacy of using atorvastatin in patients with chronic obstructive pulmonary disease (COPD) with concomitant type 2 diabetes mellitus (DM).

Material and methods. 49 COPD patients with concomitant type 2 diabetes were examined. Patients were prescribed atorvastatin 20-40 mg once daily for 6 months in addition to standard therapy.

In the examination of patients used the CAT-test, the test with a 6-minute walk, the integral BODE index, spirometry, bio-impedance analysis. The dynamics of treatment also evaluated the lipid spectrum of the blood, carbohydrate metabolism, functional state of the endothelium, the level of leptin, adiponectin, resistin, tumor necrosis factor- $\alpha$ (TNF $\alpha$ ), transforming growth factor- $\beta 1$ (TGF $\beta 1)$ and C-reactive protein (SRB) blood.

Results. In the analysis of bioimpedansometry indicators in the dynamics of atorvastatin treatment in patients with COPD with concomitant type 2 diabetes, a significant decrease in the percentage of fat, visceral fat and BMI was found. When evaluating spirometry, there was a tendency for an increase in FEVI, but no confidence ( $p>0.05)$.

Six months of atorvastatin treatment in COPD patients with concomitant diabetes mellitus type 2 showed a significant decrease in shortness of breath by $61.8 \%$ ( $p>$ $0.05)$, a decrease in the SAT score by 40.7\% $(p<0.001)$ and an increase in the distance traveled by $14.9 \%$ in six minutes $(p<0.001)$. The BODE integral index decreased by $49.9 \%$ at the end of treatment $(p<0.001)$.

Analysis of blood lipid spectra showed a significant decrease in total cholesterol, LDL cholesterol, LDL cholesterol, TG $(p<0.001)$, but no significant changes in HDL cholesterol ( $p>0.05$ ).

The levels of adipocytokines (leptin and resistin), TNF $\alpha, T G F \beta 1$, and CRP in serum when using atorvastatin in COPD patients with concomitant type 2 diabetes significantly decreased in the absence of significant changes in adiponectin $(p>0.05)$.

Analysis of endothelial functional status indicators at the end of treatment showed a probable $35.3 \%$ increase in nitrate/nitrite level, a 2-fold decrease in CCEE $(p<0.001)$, and a 2.3-fold increase in ET-1 $(p<0.001)$.

According to the study, atorvastatin had no significant effect on carbohydrate metabolism, but did improve blood lipid spectrum. Therefore, in patients with COPD with concomitant type 2 diabetes, the use of atorvastatin does not impair the course of diabetes, but may possibly reduce cardiovascular risk by improving carbohydrate metabolism.

Given that statins improve the functional state of the endothelium, the effect of atorvastatin on endothelial dysfunction in patients with COPD with concomitant 
Original research

type 2 diabetes has been investigated.

Conclusions. Thus, the six-month application of atorvastatin in the complex treatment of patients with COPD with concomitant type 2 diabetes improves body composition, exercise tolerance, quality of life, prognosis and reduces the severity of comorbid pathology against the backdrop of manifestations of systemic inflammation.

Вступ. Відомо, що ХОЗЛ асоціюється з хронічним системним запаленням низької градації та коморбідністю [1]. Сьогодні хоча і досягнуті успіхи в лікуванні ХОЗЛ, проте, окрім впливу на бронхіальну прохідність не вказується ефективності використання засобів із протизапальною дією. Встановлено, що статини, окрім безпосереднього впливу на ліпідний обмін, володіють плейотропними властивостями, зокрема протизапальними, антиоксидантними, впливом на функцію ендотелію [2]. Проведені чисельні дослідження, а також метааналізи показали ефективність їх застосування щодо впливу на кардіоваскулярну смертність, зниження частоти загострення і смертності серед пацієнтів на ХОЗЛ [2,3]. Деякі дослідження демострують також покращення функції легень, толерантність до фізичного навантаження, зниження показників запалення та задишки при використанні в лікуванні хворих на ХОЗЛ [4]. Інші, навпаки, показують відсутність впливу статинів на частоту і тяжкість загострення [4,5]. Досі до кінця не вивчена роль статинів у патогенезі ХОЗЛ, особливо за коморбідного його перебігу із серцево-судинною патологією та цукровим діабетом типу 2.

Мета дослідження - вивчити ефективність застосування аторвастатину у хворих на ХОЗЛ із супутнім ЦД типу 2.

Матеріал і методи. Обстежено 49 пацієнтів на ХОЗЛ із супутнім ЦД типу 2. Середній вік хворих становив $60,67 \pm 1,22$. Тривалість захворювання 9,16 $\pm 0,71$. Співвідношення чоловіків та жінок - 40/9. Індекс пачко-років складав 17,39 $\pm 2,82$. Діагноз ХОЗЛ встановлювали за рекомендаціями GOLD 2017 року. Критеріями включення пацієнтів у дослідження були вік пацієнтів більше 40 років, співвідношення ОФВ1/ФЖЕЛ менше 0,7, респіраторна симтоматика, група пацієнтів В та D, III і IV стадія за класифікацією GOLD, наявність змін ліпідного обміну, компенсований ЦД типу 2. Пацієнтам, окрім стандартної терапії, призначали аторвастатин 20-40 мг 1 раз на добу впродовж шести місяців.

При обстеженні пацієнтів використовували САТтест, тест із 6-хвилинною ходьбою, інтегральний індекс BODE, спірометрію (спірограф "BTL 08 Spiro Pro"

Таблиця 1

Показники біоімпедансометрії, функції зовнішнього дихання, тесту із 6-хвилинною ходьбою, ТОХ-тесту, шкали задишки та інтегрального індексу ВОDЕ у хворих на ХОЗЛ із супутнім цукровим діабетом типу 2 у динаміці лікування аторвастатином

\begin{tabular}{|c|c|c|c|}
\hline \multirow{2}{*}{ Параметри } & \multicolumn{3}{|c|}{ Аторвастатин } \\
\cline { 2 - 4 } & до лікування & $\begin{array}{c}\text { через 6 місяців } \\
\text { після лікування }\end{array}$ & $\mathrm{p}$ \\
\hline \% жиру в організмі & $30,94 \pm 1,07$ & $28,08 \pm 1,09$ & $\mathrm{p}<0,001$ \\
\hline М'язова маса, кг & $63,04 \pm 1,55$ & $61,09 \pm 1,56$ & $\mathrm{p}>0,05$ \\
\hline $\begin{array}{c}\text { Рівень вісцерального } \\
\text { жиру }\end{array}$ & $15,87 \pm 0,53$ & $13,55 \pm 0,36$ & $\mathrm{p}<0,05$ \\
\hline ІМТ, кг/м2 & $34,09 \pm 0,61$ & $30,77 \pm 0,51$ & $\mathrm{p}<0,001$ \\
\hline $\begin{array}{c}\text { ОФВ1, \% від належного } \\
\text { значення }\end{array}$ & $46,37 \pm 1,89$ & $49,93 \pm 2,16$ & $\mathrm{p}>0,05$ \\
\hline $\begin{array}{c}\text { Тест із 6-хвилинною } \\
\text { ходьбою }\end{array}$ & $288,26 \pm 13,29$ & $338,78 \pm 14,21$ & $\mathrm{p}<0,05$ \\
\hline тМRС шкала задишки, & $2,12 \pm 0,17$ & $1,31 \pm 0,14$ & $\mathrm{p}<0,05$ \\
\hline бали & $19,78 \pm 1,25$ & $14,06 \pm 1,01$ & $\mathrm{p}<0,001$ \\
\hline САТ-тест, бали & $5,41 \pm 0,31$ & $3,61 \pm 0,25$ & $\mathrm{p}<0,001$ \\
\hline \begin{tabular}{c} 
Індекс ВОDЕ \\
\hline
\end{tabular} & & & \\
\hline
\end{tabular}

Примітка: * — відмінності вірогідні порівняно з даними після лікування між контрольною та основною групами $(\mathrm{p}<0,05)$. 
Показники вуглеводного та ліпідного обмінів у хворих на ХОЗЛ із супутнім цукровим діабетом типу 2 у динаміці лікування аторвастатином

\begin{tabular}{|c|c|c|c|}
\hline \multirow{2}{*}{ Параметри } & \multicolumn{3}{|c|}{ Аторвастатин } \\
\cline { 2 - 4 } & до лікування & $\begin{array}{c}\text { через 6 місяців } \\
\text { після лікування }\end{array}$ & $\mathrm{P}$ \\
\hline Глюкоза натще, ммоль/л & $7,45 \pm 0,35$ & $7,21 \pm 0,29$ & $\mathrm{p}>0,05$ \\
\hline НьА1с, \% & $6,25 \pm 0,26$ & $6,13 \pm 0,23$ & $\mathrm{p}>0,05$ \\
\hline $\begin{array}{c}\text { Загальний холестерин, } \\
\text { ммоль/л }\end{array}$ & $6,79 \pm 0,17$ & $4,76 \pm 0,11$ & $\mathrm{p}<0,001$ \\
\hline $\begin{array}{c}\text { Тригліцероли, ммоль/л } \\
\text { Холестерин ліпопроте- } \\
\text { інів низької щільності, } \\
\text { ммоль/л }\end{array}$ & $2,59 \pm 0,10$ & $1,77 \pm 0,05$ & $\mathrm{p}<0,001$ \\
\hline $\begin{array}{c}\text { Холестерин ліпопроте- } \\
\text { інів високої щільності, } \\
\text { ммоль/л }\end{array}$ & $0,97 \pm 0,03$ & $54,35 \pm 1,18$ & $\mathrm{p}<0,001$ \\
\hline $\begin{array}{c}\text { Холестерин ліпопротеїнів } \\
\text { дуже низької щільності, } \\
\text { ммоль/л }\end{array}$ & $1,17 \pm 0,05$ & $1,01 \pm 0,03$ & $\mathrm{p}>0,05$ \\
\hline
\end{tabular}

(Великобританія), біоімпедансний аналіз (портативний апарат ВC-601 (TANITA, Японія).

Оцінювали до та після лікування також ліпідний спектр крові (загальний ХC, тригліцероли (ТГ), ХC ЛПНЩ, ХС ліпопротеїнів дуже низької щільності (XC ЛПДНЩ) та ХС ЛПВЩ), вуглеводний обмін (глюкоза в крові натще, глікозильований гемоглобіном (HbA1c)), функціональний стан ендотелію (вміст у крові стабільних метаболітів монооксиду нітрогену (нітритів/нітратів), ЕТ-1, КЦЗЕ). У динаміці лікування за допомогою наборів для імуноферментного аналізу в сироватці крові визначали рівень лептину (Diagnostics Biochem Canada Inc, Канада), адипонектину (Assay, США) та резистину (Mediagnost, Німеччина), ФНП $\alpha$ та ТФР $\beta 1$ (Bender MedSystems GmbH, Австрія), а також рівень СРБ (Humatex CRP «HUMAN», Німеччина).

Розрахунки проводились з використанням програми Statistica, версія 10,0.

Результати дослідження та їх обговорення. При аналізі показників біоімпедансометрії в динаміці лікування аторвастатином у хворих на ХОЗЛ із супутнім ЦД типу 2 встановлено достовірне зниження \% жирової маси, вісцерального жиру та IMT на 10,2, 17,1 та 10,8\% відповідно (табл. 1). М'язова маса вірогідних змін не зазнавала. При оцінці спірометрії, відзначалась тенденція до зростання ОФВ1, проте достовірності не було ( $\mathrm{p}>0,05)$.

Через шість місяців лікування аторвастатином у хворих на ХОЗЛ із супутнім ЦД типу 2 спостерігалось достовірне зниження задишки на $61,8 \%$ (p>0,05), зменшення кількості балів за САТ-тестом на 40,7\% $(\mathrm{p}<0,001)$ та зростання відстані, пройденої за шість хвилин, на 14,9\% (p<0,001). Інтегральний індекс BODE наприкінці лікування зменшувався на 49,9\% (p<0,001).
При оцінці вуглеводного обміну (табл. 2) у динаміці лікування аторвастатином не відзначалось достовірних змін ( $>>0,05)$. Аналіз показників ліпідного спектра крові показав достовірне зниження загального ХС на 42,6\% $(\mathrm{p}<0,001)$, ХС ЛПНЩ - на 32,9\% (p<0,001), ХС ЛПДНЩ — на 42,7\% (p<0,001), ТГ на 46,3\% (p<0,001), проте ХС ЛПВЩ достовірних змін не зазнавав $(\mathrm{p}>0,05)$.

Рівень адипоцитокінів у сироватці крові (табл. 3) при використанні аторвастатину достовірно зазнавали змін з боку лептину (знижувався на $37,9 \%(\mathrm{p}<0,001)$ ), резистину (на $12,6 \%(\mathrm{p}<0,05))$ при відсутності достовірних змін адипонектину ( $\mathrm{p}>0,05)$.

Про- та протизапальні цитокіни та СРБ також достовірно змінювалися в динаміці лікування у хворих на ХОЗЛ із супутнім ЦД типу 2, зокрема ФНП $\alpha$ знижувався у 2,1 раза ( $<<0,001)$, ТФР $\beta 1$ на $57,5 \%$ ( $<<0,001)$ та СРБ на 98,5\% відповідно ( $<<0,001)$.

Аналіз показників функціонального стану ендотелію наприкінці лікування показав вірогідне зростання рівня нітратів/нітритів на 35,3\% ( $<0,001)$, зниження КЦЗЕ у 2 рази $(\mathrm{p}<0,001)$ та ЕT-1 у 2,3 раза $(\mathrm{p}<0,001)$.

Отже, результати нашого дослідження показали, що при використанні в комплексному лікуванні аторвастатину впродовж шести місяців у хворих на ХОЗЛ із супутнім ЦД типу 2 спостерігається покращення складу тіла пацієнтів за даними біоімпедансометрії, зокрема зниження \% жирової маси, рівня вісцерального жиру, IMT та тенденція до покращення м'язової маси.

У літературі щодо впливу статинів на функцію зовнішнього дихання у хворих на ХОЗЛ існують неоднозначні результати. Деякими дослідниками отримані позитивні ефекти статинів на спірометричні показники [3], в інших достовірних змін не було [6]. Наші результати показали лише тенденцію до зростання ОФВ1 на- 
Original research

Таблиця 3

Показники рівня адипоцитокінів, про- та протизапальних цитокінів, С-реативного білка у сироватці крові та функціонального стану ендотелію у хворих на ХОЗЛ із супутнім цукровим діабетом типу 2 у динаміці лікування аторвастатином

\begin{tabular}{|c|c|c|c|}
\hline \multirow{2}{*}{ Параметри } & \multicolumn{3}{|c|}{ Аторвастатин } \\
\cline { 2 - 4 } & до лікування & $\begin{array}{c}\text { через 6 місяців після } \\
\text { лікування }\end{array}$ & $\mathrm{P}$ \\
\hline $\begin{array}{c}\text { Лептин, нг/мл } \\
\mathrm{n}=35\end{array}$ & $53,12 \pm 4,58$ & $38,51 \pm 3,91$ & $\mathrm{p}<0,001$ \\
\hline $\begin{array}{c}\text { Резистин, нг/мл } \\
\mathrm{n}=35\end{array}$ & $15,30 \pm 1,11$ & $13,59 \pm 0,79$ & $\mathrm{p}<0,05$ \\
\hline $\begin{array}{c}\text { Адипонектин, нг/мл } \\
\mathrm{n}=35\end{array}$ & $4,79 \pm 0,27$ & $5,23 \pm 0,31$ & $\mathrm{p}>0,05$ \\
\hline $\begin{array}{c}\text { ФНП }, \text { пг/мл } \\
\mathrm{n}=35\end{array}$ & $659,47 \pm 33,01$ & $320,20 \pm 33,71$ & $\mathrm{p}<0,001$ \\
\hline $\begin{array}{c}\text { ТФР } \beta 1, \text { пг/мл } \\
\mathrm{n}=35\end{array}$ & $16116,91 \pm 875,15$ & $10230,03 \pm 646,21$ & $\mathrm{p}<0,001$ \\
\hline $\begin{array}{c}\text { С-реактивний білок } \\
\mathrm{n}=47\end{array}$ & $8,12 \pm 0,51$ & $4,09 \pm 0,35$ & $\mathrm{p}<0,001$ \\
\hline $\begin{array}{c}\text { Рівень нітритів/нітратів, } \\
\text { мкмоль/л }\end{array}$ & $14,41 \pm 0,67$ & $22,28 \pm 0,77$ & $\mathrm{p}<0,001$ \\
\hline $\begin{array}{c}\text { Кількість циркулюючих } \\
\text { злущених ендотеліоцитів, } \\
104 / л \mathrm{n}=46\end{array}$ & $19,21 \pm 0,71$ & $9,80 \pm 0,49$ & $\mathrm{p}<0,001$ \\
\hline $\begin{array}{c}\text { Ендотелін-1, } \\
\text { пмоль/л n=39 }\end{array}$ & $0,28 \pm 0,02$ & $0,13 \pm 0,01$ & \\
\hline
\end{tabular}

прикінці лікування аторвастатином.

У контрольованому пілотному дослідженні групою авторів [3] показаний позитивний вплив аторвастатину на толерантність хворих до фізичного навантаження за тестом із 6-хвилинною ходьбою та покращення якості життя за тестом св. Георгія. Ми отримали також покращення суб'єктивного сприйняття хворими на ХОЗЛ із супутнім ЦД типу 2 за САТ-тестом та толерантності до фізичного навантаження в динаміці лікування аторвастатином.

Відомо, що інтегральний індекс BODE характеризує прогноз хворих на ХОЗЛ, а також тяжкість перебігу. Останнім часом його використовують також для оцінки ефективності терапії [1]. За результатами нашого дослідження, індекс BODE наприкінці лікування достовірно знижувався. Отже, можна припустити, що аторвастатин покращує прогноз хворих на ХОЗЛ із супутнім ЦД типу 2. Ряд досліджень показали зниження смертності пацієнтів із ХОЗЛ за використання статинів $[2,7]$.

За результатами нашого дослідження, аторвастатин достовірно не впливав на вуглеводний обмін, але покращував ліпідний спектр крові. Отже, у хворих на ХОЗЛ із супутнім ЦД типу 2 використання аторвастатину не погіршує перебіг ЦД, проте, можливо, призводить до зменшення кардіоваскулярного ризику, покращуючи показники вуглеводного обміну.
За результатами контрольованого пілотного дослідження, 12-тижневе лікування аторвастатином у хворих на ХОЗЛ [3] не призводило до достовірних змін показників ліпідного спектра крові, проте інші автори показують позитивні ефекти статинів на ліпідний обмін [4]. Можливо такі різні результати пов'язані з різними дозами аторвастатину, тривалості терапії, супутніх захворювань та інших факторів, які могли вплинути на результати дослідження.

Багатьма дослідженнями доведені протизапальні ефекти статинів $[2,3,7,8]$. Нами показано, що аторвастатин достовірно впливав на показники системного запалення (знижував рівні у сироватці крові адипоцитокінів, про- та протизапальних цитокінів, СРБ).

Враховуючи, що статини покращують функціональний стан ендотелію, ми вивчали вплив аторвастатину на ендотеліальну дисфункцію у хворих на ХОЗЛ із супутнім ЦД типу 2. Нами встановлено зростання рівня нітратів/нітритів та зниження КЦЗЕ та рівня ЕТ-1 у сироватці крові.

Висновки. Отримані результати дослідження показують, що шестимісячне використання аторвастатину в комплексному лікуванні хворих на хронічне обструктивне захворювання легень із супутнім цукровим діабетом типу 2 покращує склад тіла, толерантність до фізичного навантаження, якість життя, прогноз та 
тяжкість перебігу коморбідної патології на тлі зниження проявів системного запалення, ендотеліальної дисфункції із покращенням ліпідного спектра крові.

Перспективи подальших досліджень. Перспективним є подальше дослідження ефективності статинів при ХОЗЛ із супутнім ЦД2 з урахуванням поліморфізму гена MDR1 (C3435 T).

\section{Список літератури}

1. Hanson C, Bowser EK, Frankenfield DC, Piemonte TA. Chronic Obstructive Pulmonary Disease: A 2019 Evidence Analysis Center Evidence-Based Practice Guideline. J Acad Nutr Diet. 2020 Feb 17. pii: S2212-2672(19)31696-X.

2. Walton GM, Stockley JA, Griffiths D, Sadhra CS, Purvis T, Sapey E. Repurposing Treatments to Enhance Innate Immunity. Can Statins Improve Neutrophil Functions and Clinical Outcomes in COPD? J Clin Med. 2016 Oct 11;5(10). pii: E89.

3. Mroz RM, Lisowski P, Tycinska A, Bierla J, Trzeciak PZ, Minarowski L, Duszewska AM. Anti-inflammatory effects of atorvastatin treatment in chronic obstructive pulmonary disease. A controlled pilot study. J. Physiol. Pharmacol. 2015; 66(1): 111-28.

4. Zhang W, Zhang Y, Li CW, Jones P, Wang C, Fan Y. Effect of statins on COPD: a meta-analysis of randomized controlled trials. Chest. 2017; 152(6): 1159-68.

5. Citgez E, van der Palen J, Koehorst-ter Huurne K, Movig K, van der Valk P, Brusse-Keizer M. Statins and morbidity and mortality in COPD in the COMIC study: a prospective COPD cohort study. BMJ open respiratory research. 2016; 3(1): e000142.

6. Balaguer C, Peralta A, Ríos Á, Iglesias A, Valera JL, Noguera A, Sala-Llinas E. Effects of simvastatin in chronic obstructive pulmonary disease: Results of a pilot, randomized, placebo-controlled clinical trial. Contemporary clinical trials communications. 2016; 2: 91-96.

7. Raymakers AJ, Sadatsafavi M, Sin DD, De Vera MA, Lynd LD. The impact of statin drug use on all-cause mortality in patients with COPD: a population-based cohort study. Chest. 2017: 152(3), 486-93.

8. Maneechotesuwan K, Kasetsinsombat K, Wongkajornsilp A,
Barnes PJ. Simvastatin up-regulates adenosine deaminase and suppresses osteopontin expression in COPD patients through an IL-13-dependent mechanism. Respiratory research. 2016; 17(1): 104 .

\section{References}

1. Hanson C, Bowser EK, Frankenfield DC, Piemonte TA. Chronic Obstructive Pulmonary Disease: A 2019 Evidence Analysis Center Evidence-Based Practice Guideline. J Acad Nutr Diet. 2020 Feb 17. pii: S2212-2672(19)31696-X.

2. Walton GM, Stockley JA, Griffiths D, Sadhra CS, Purvis T, Sapey E. Repurposing Treatments to Enhance Innate Immunity. Can Statins Improve Neutrophil Functions and Clinical Outcomes in COPD? J Clin Med. 2016 Oct 11;5(10). pii: E89.

3. Mroz RM, Lisowski P, Tycinska A, Bierla J, Trzeciak PZ, Minarowski L, Duszewska AM. Anti-inflammatory effects of atorvastatin treatment in chronic obstructive pulmonary disease. A controlled pilot study. J. Physiol. Pharmacol. 2015; 66(1): 111-28.

4. Zhang W, Zhang Y, Li CW, Jones P, Wang C, Fan Y. Effect of statins on COPD: a meta-analysis of randomized controlled trials. Chest. 2017; 152(6): 1159-68.

5. Citgez E, van der Palen J, Koehorst-ter Huurne K, Movig K, van der Valk P, Brusse-Keizer M. Statins and morbidity and mortality in COPD in the COMIC study: a prospective COPD cohort study. BMJ open respiratory research. 2016; 3(1): e000142.

6. Balaguer C, Peralta A, Ríos Á, Iglesias A, Valera JL, Noguera A, Sala-Llinas E. Effects of simvastatin in chronic obstructive pulmonary disease: Results of a pilot, randomized, placebo-controlled clinical trial. Contemporary clinical trials communications. 2016; 2: 91-96.

7. Raymakers AJ, Sadatsafavi M, Sin DD, De Vera MA, Lynd LD. The impact of statin drug use on all-cause mortality in patients with COPD: a population-based cohort study. Chest. 2017; 152(3): 486-93.

8. Maneechotesuwan K, Kasetsinsombat K, Wongkajornsilp A, Barnes PJ. Simvastatin up-regulates adenosine deaminase and suppresses osteopontin expression in COPD patients through an IL-13-dependent mechanism. Respiratory research. 2016; 17(1): 104

\section{Відомості про авторів}

Чернецька Н. В. - аспірант кафедри внутрішньої медицини та інфекційних хвороб ВДНЗ України «Буковинський державний медичний університет», м. Чернівці, Україна.

\section{Сведения об авторах}

Чернецкая Н. В. - аспирант кафедры внутренней медицины и инфеционных заболеваний ВГУЗ Украины «Буковинский государственный медицинский университет», г. Черновцы, Украина.

\section{Information about the author}

Chernetska N. V. - post-graduate student of the Department of Internal Medicine and Infection Diseases of HSEI of Ukraine "Bukovinian State Medical University", Chernivtsi, Ukraine.

Надійшла до редакції 24.02.2020 